\title{
UJ KANDUNGAN FITOKIMIA DARI DAUN NANGKA (Artocarpus heteropyllus) DAN DAUN KELOR (Moringa oleifera) SEBAGAI PAKAN TAMBAHAN BAGI TERNAK KAMBING
}

\author{
Angelia Utari Harahap, Lili Warly, Hermon, Suyitman, dan Evitayani \\ Fakultas Peternakan Universitas Andalas, Limau Manis Padang \\ e-mail:angeliaharahap@yahoo.co.id
}

\begin{abstract}
ABSTRAK
Uji fitokimia dilakukan untuk memberikan deskripsi senyawa kelompok yang terkandung dalam ekstrak, salah satunya dari bahan pakan tambahan alternatif yang digunakan berasal dari daun nangka (Artocarpus heterophyllus) dan daun kelor (Moringa oleifera) merupakan sumber tanin yang potensial digunakan sebagai proteksi protein pakan yang berkualitas tinggi dalam meningkatkan produktivitas ternak kambing. Penelitian ini bertujuan untuk mengetahui golongan senyawa kimia yang terkandung dalam ekstrak daun nangka dan daun kelor. Sampel yang digunakan dalam penelitian ini adalah daun nangka dan daun kelor yang diperoleh di wilayah Tapanuli Selatan, Sumatera Utara. Daun nangka dan daun kelor terlebih dahulu diekstraksi selanjutnya dilakukan uji fitokimia untuk mendeteksi adanya senyawa aktif alkaloid, flavonoid, saponin, fenolat, triterpenoida/steroida, dan tanin. Hasil penelitian menunjukkan bahwa daun nangka dan daun kelor mengandung senyawa alkaloid, flavonoid, fenolat, triterpenoida/steroida, dan tanin.
\end{abstract}

Kata kunci: daun kelor, daun nangka, fitokimia, tanin

\section{PHYTOCHEMICAL CONTENT FROM NANGKA LEAVES (Artocarpus heteropyllus) AND KELOR LEAVES (Moringa oleifera) AS ADDITIONAL FEED FOR GOAT LIVESTOCK}

\begin{abstract}
Phytochemical tests were carried out to provide a description of the group compounds contained in the extract, one of which was an alternative feed additive used from jackfruit leaves and Moringa oleifera leaves which were potential sources of tannins used as high-quality protein protection in increasing the productivity of goats. This study aims to determine the class of chemical compounds contained in jackfruit and Moringa leaf extracts. The samples used in this study were Jackfruit leaves and Moringa leaves which were obtained in the South Tapanuli region, North Sumatra. Jackfruit leaves and Moringa leaves are first extracted then phytochemical tests are performed to detect the presence of active compounds of alkaloids, flavonoids, saponins, phenolics, triterpenoids / steroids, and tannins. The results showed that jackfruit leaves and Moringa leaves contain alkaloids, flavonoids, phenolics, triterpenoids / steroids, and tannins.
\end{abstract}

Key words: jacfruit leaves, moringa leaves, phytochemical, tannin

\section{PENDAHULUAN}

Pada saat ini banyak dimanfaatkan limbah pertanian yang telah dicobakan sebagai bahan pakan, Ketersediaan pakan di daerah tropis secara umum sangat bergantung pada musim, kualitas yang rendah dan kontinuitasnya yang tidak stabil karena pada musim kemarau terjadi kekurangan pakan dan sebaliknya pada musim penghujan pakan akan melimpah, Salah satu cara mengatasi masalah ketersediaan pakan adalah dengan penggunaan bahan pakan alternatif dapat berasal dari hijauan seperti halnya daun nangka dan daun kelor (Hastuty, 2017).
Nangka adalah pohon tanaman buah yang termasuk dalam suku Moraceae yang berasal dari India, Indonesia, Afrika Tengah, Florida, Brazil, Australia, dan Kepulauan Pasifik. Bagian dari tanaman nangka seperti batang, akar, daun dan buah mempunyai kandungan obat. Secara spesifik daun nangka juga mengandung sapogenins, cycloartenone, cycloartenol, $\beta$-sitosterol, dan tanin. Tanaman nangka (Artocarpus heterophyllus) memiliki famili yaitu Moraceae yang juga memiliki potensi sebagai agen sitotoksik yang mengandung fenolik tinggi, termasuk flavonoid yang memiliki toksisitas tinggi.

Di Indonesia, pohon kelor banyak dimanfaatkan 
sebagai pagar hidup, yang ditanam di sepanjang ladang atau tepi sawah, yang berfungsi sebagai tanaman penghijau (Wahyono et al., 2017). Selain itu, tanaman kelor juga dikenal sebagai tanaman berkhasiat obat dengan memanfaatkan seluruh bagian dari tanaman kelor mulai dari daun, kulit batang, biji, hingga akarnya. Banyak penelitian tanaman kelor yang dilakukan di luar negeri dengan menggunakan sampel yang berasal dari luar Indonesia. Namun, penelitian ini masih terbatas dilakukan di Indonesia, oleh karena itu penting kiranya untuk melakukan penelitian ini menggunakan daun nangka dan daun kelor yang berasal dari Indonesia khususnya daerah Tapanuli Selatan, Sumatera Utara. Pada penelitian ini akan dilakukan skrining fitokimia terlebih dahulu dari daun nangka dan daun kelor sebagai pakan hijauan tambahan pada ternak kambing.

\section{MATERI DAN METODE}

\section{Bahan}

Bahan uji yang digunakan yaitu daun nangka dan daun kelor yang telah dikeringkan dan dihaluskan dengan blender. Bahan kimia yang digunakan adalah sebagai berikut, 1) bahan pada saat proses maserasi menggunakan daun kelor kering dan aseton; 2) pada saat proses skrining fitokimia menggunakan Reagen Mayer, Reagen Wagner, Reagen Bouchardat, asam sulfat pekat, $\mathrm{HCl} 2 \mathrm{~N}$, besi (III) klorida $1 \%, \mathrm{Mg}, \mathrm{HCl}$ $2 \%$, asam asetat anhidrat

\section{Metode}

Ekstraksi daun nangka dan daun kelor dengan proses ekstraksi dilakukan dengan cara maserasi. Bubuk daun nangka dan daun kelor diekstraksi dua kali dengan n-heksan (1:4 b/v). Residunya diekstraksi kembali sebanyak dua kali dengan etil asetat (1:4 b/v). Residu etil asetat selanjutnya diekstraksi dua kali dengan metanol (1:4 b/v). Masing-masing filtrat diuapkan pelarutnya dengan menggunakan rotavapor. Ekstrak yang diperoleh digunakan sebagai sampel untuk analisa fitokimia analisa fitokimia ekstrak dan minyak atsiri analisa fitokimia ekstrak n-heksana, etil asetat dan metanol buah andaliman dilakukan dengan beberapa metode.

\section{Parameter Penelitian Maserasi}

Sampel daun nangka dan daun kelor kering yang telah halus kemudian ditimbang sebanyak $50 \mathrm{~g}$. Sampel direndam dalam $200 \mathrm{ml}$ aseton, setelah itu diekstrak dengan gelombang ultrasonik pada frekuensi $50 \mathrm{kHz}$ selama 10 menit dan dilakukan maserasi selama 2 jam. Setelah 2 jam, daun nangka dan daun kelor kemudian disaring untuk memperoleh filtratnya dan residunya dimaserasi kembali dengan aseton selama 2 jam. Proses maserasi dilakukan sebanyak empat kali. Filtrat yang diperoleh kemudian dijadikan satu lalu dievaporasi menggunakan rotary evaporator sehingga diperoleh ekstrak kental sebanyak 11,5684 g (Agung et al., 2016)

Setelah diperoleh ekstrak kental, kemudian dilakukan uji skrining fitokimia berupa uji flavonoid, uji tanin, uji saponin, uji alkaloid, uji steroid dan triterpenoid.

\section{Uji Flavonoid}

Pemeriksaan flavonoid dilakukan dengan cara yaitu ekstrak dari hasil maserasi sampel diambil sepucuk spatula, kemudian ditambahkan sepucuk spatula serbuk $\mathrm{Mg}$ dan empat tetes $\mathrm{HCl} 2 \%$. Keberadaan flavonoida akan ditunjukkan dengan terjadinya perubahan warna filtrat menjadi jinggamerah (Agung et al., 2016).

\section{Uji Saponin}

Ekstrak aseton dimasukkan ke dalam tabung reaksi kemudian ditambahkan air panas, didinginkan, kemudian dikocok selama 10 detik. Setelah itu diamati perubahan yang terjadi. Kemudian ditambahkan kembali 1 tetes $\mathrm{HCl} 2 \mathrm{~N}$ dan diamati kembali perubahan yang terjadi. Hasil positif apabila muncul busa stabil selama 10 menit (Agung et al., 2016).

\section{Uji Alkaloid}

Ekstrak yang akan diperiksa dimasukkan ke dalam tabung reaksi, kemudian ditambahkan beberapa tetes $\mathrm{HCl} 2 \mathrm{~N}$ dan air suling, setelah itu dipanaskan diatas penangas air selama 2 menit, kemudian didinginkan dan disaring. Filtrat yang digunakan untuk uji alkaloid adalah sebagai berikut: a. Tiga tetes filtrat ditambahkan dengan 2 tetes larutan pereaksi Mayer, kemudian dilakukan pengamatan yang terjadi. b. Tiga tetes filtrat ditambahkan dengan 2 tetes larutan pereaksi Bouchardat, kemudian dilakukan pengamatan yang terjadi. c. Tiga tetes filtrat ditambahkan dengan 2 tetes larutan pereaksi Wagner kemudian dilakukan pengamatan yang terjadi. Alkaloid positif jika terjadi endapan atau kekeruhan paling sedikit dua dari tiga percobaan diatas Ciri khas dari reaksi positif alkaloid adalah terbentuknya warna kuning kecoklatan dengan pereaksi Wagner dan endapan kuning dengan pereaksi Meyer (Agung et al., 2016).

\section{Uji Steroid dan Triterpenoid}

Ekstrak aseton yang akan diperiksa dimasukkan ke dalam tabung reaksi, kemudian ditambahkan 2 - 3 tetes asam asetat anhidrat, lalu diaduk secara perlahan beberapa saat sampai kering, kemudian ditambahkan $1-2$ tetes asam sulfat pekat dan 
diamati pewarnaan yang timbul. Pewarnaan merah atau merah ungu memberikan indikasi triterpenoid sementara pewarnaan hijau - biru untuk steroid (Agung et al., 2016).

\section{HASIL DAN PEMBAHASAN}

Ekstraksi adalah proses pemisahan secara kimia dan fisika kandungan zat simplisia menggunakan pelarut yang sesuai. Tujuan ekstraksi adalah untuk menarik komponen kimia yang terdapat pada bahan alam. Ekstraksi ini didasarkan pada prinsip perpindahan massa komponen zat ke dalam pelarut, yaitu perpindahan mulai terjadi pada lapisan antar muka kemudian berdifusi masuk ke dalam pelarut. Teknik ekstraksi yang digunakan dalam penelitian ini adalah maserasi karena selain pengerjaannya lebih mudah, peralatan yang digunakan sederhana. Proses maserasi sangat menguntungkan dalam ekstraksi senyawa bahan alam karena dengan perendaman sampel tumbuhan akan terjadi pemecahan dinding dan membran sel akibat perbedaan tekanan antara di dalam dan di luar sel, sehingga metabolit sekunder yang ada dalam sitoplasma akan terlarut dalam pelarut organik dan ekstraksi senyawa akan sempurna (Pasaribu, 2009). Selain itu proses maserasi dilakukan tanpa pemanasan sehingga tidak terjadi kerusakan pada senyawa metabolit sekunder yang akan dianalisis. Sebelum proses maserasi dilakukan, daun nangka dan daun kelor yang akan digunakan terlebih dahulu dibersihkan kemudian dikeringkan pada suhu ruang tanpa penyinaran sinar matahari. Hal ini dikarenakan paparan sinar matahari secara langsung pada suhu tinggi dapat merusak dan menyebabkan terdegradasinya senyawa yang terdapat dalam sampel. Setelah kering, daun kelor kemudian dihaluskan dengan menggunakan blender (Agung et al., 2016).

Skrining fitokimia setelah memperoleh ekstrak kental, ekstrak tersebut kemudian diuji golongan senyawa kimia yang terkandung didalamnya menggunakan uji skrining fitokimia. Pada tahap ini dilakukan lima macam pemeriksaan yaitu pemeriksaan alkaloid, flavonoid, tanin, saponin, steroid dan triterpenoid. Hasil dari uji skrining fitokimia tersebut disajikan pada Tabel 1.

Tabel 1. Hasil Uji Fitokimia

\begin{tabular}{lcc}
\hline \multicolumn{1}{c}{ Parameter Uji } & Daun Nangka & Daun Kelor \\
\hline Alkaloid & + (Positif) & + (Positif) \\
Flavonoid & + (Positif) & + (Positif) \\
Fenolik & + (Positif) & + (Positif) \\
Saponin & (-) Negatif & (-) Negatif \\
Steroid & + (Positif) & + (Positif) \\
Triterpenoid & + (Positif) & + (Positif) \\
\hline
\end{tabular}

Sumber : Laboratorium Kimia Organik Bahan Alam FMIPA Unand (2020)
Hasil uji fitokimia menunjukkan bahwa daun nangka dan daun kelor mengandung berbagai jenis senyawa metabolit sekunder seperti fenolik, saponin, flavonoid, tanin, triterpenoid dan alkaloid. Hasil penelitian ini didukung oleh perubahan warna yang terjadi karena reagen pasokan untuk mengekstrak daun nangka dan daun kelor. Tanaman yang lebih tinggi memiliki flavonoid yang baik pada bagian vegetatif terutama pada bunga. Flavonoid sebagai pigmen bunga memainkan peran penting. Fungsi lain dari flavonoid adalah mampu menyerap sinar ultraviolet untuk mengarahkan serangga, mengatur tanaman, mengatur fotosintesis, kerja anti-mikroba dan anti-virus sehingga dapat bekerja pada serangga (Yusriana et al., 2014). Efek flavonoid pada banyak organisme sangat banyak dan dapat menjelaskan mengapa tanaman yang mengandung flavonoid banyak digunakan dalam pengobatan tradisional. Selain itu, kandungan flavonoid dapat bekerja sebagai penghambat pernapasan yang kuat, menghambat reaksi oksidasi enzim dan non enzim (Gustina, 2016). Kandungan gula yang terikat dengan flavonoid cenderung menyebabkan flavonoid mudah larut dalam air yang terdapat pada Gambar 1 .

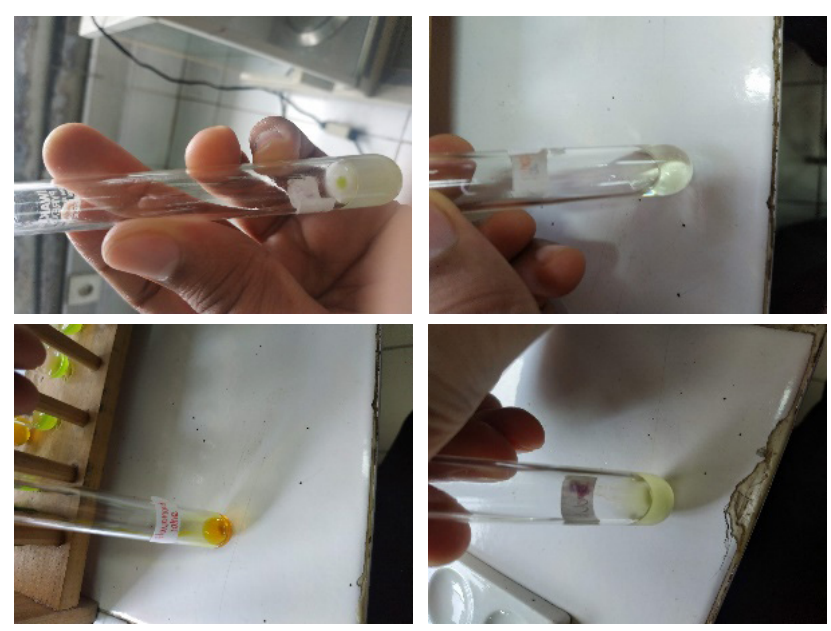

Gambar 1. Uji Fitokimia Daun Nangka

Ekstrak kimia daun nangka dan daun kelor paling tinggi diperoleh dari zat tritertenoid dan steroid, sedangkan flavonoid ditemukan dalam kandungan rendah. Steroid adalah senyawa yang berasal dari triterpenoid dan strukturnya adalah kelipatan dari 6 unit isoprena yang biasa ditemukan pada tanaman (Sulistyorini et al., 2013). Pentingnya penggunaan steroid secara fisiologis senyawa yang sangat aktif yang terlibat dalam proses kehidupan dapat mempengaruhi sistem hormonal, seperti hormon adrenal (kortison), hormon seks (estrogen dan testosteron). Lintasan biosintetik sebelum menjadi hormon steroid secara menyeluruh berasal dari asam asetat dan perubahan lebih lanjut menjadi asam mevalonat (Lykholat et al., 2016). 


\section{SIMPULAN DAN SARAN}

Senyawa metabolit sekunder yang terkandung dalam daun nangka (Artocarpus heterophyllus) dan daun kelor (Moringa oleifera) adalah golongan alkaloid, flavonoid, tanin dan steroid.

Saran dari peneliti selanjutnya yang tertarik untuk meneliti aktivitas antioksidan, sitoksisitas, total phenol content, dan antimikrobial dari daun nangka dan daun kelor untuk pakan dalam mendukung performa ternak kambing.

\section{UCAPAN TERIMA KASIH}

Penelitian ini telah berjalan dengan lancar karena telah memenangkan proposal hibah penelitian skema Kompetitif Nasional Penelitian Disertasi Doktor (PDD) pada tahun pelaksanaan 2020. Oleh karena itu, kami ingin mengucapkan terima kasih kepada DRPM Kemenristek/Brin untuk mendanai penelitian ini.

\section{DAFTAR PUSTAKA}

Agung, A., Oka, G., Made, L.2016. Identifikasi Senyawa Kimia Ekstrak Etanol Daun Kelor (Moringa oleifera L.) di Bali. Jurnal Indonesia Medicus Veterinus. Volume 5 Nomor 5. hal : 464-473.

Gustina, V.M. 2016. Sitotoksitas esktrak metanol daun sukun (Artocarpus altilis), nangka (Artocarpus heterophyllus), dan kluwih (Artocarpus camansi) terhadap sel kanker T47D. Farmasi. Skripsi. Universitas Muhammadiyah Surakarta.
Hastuty, W. 2017. Formulasi Sediaan Krim Ekstrak Etanol Daun Nangka (Artocarpus heterophyllus Lam.) sebagai Anti-Aging. Skripsi. Universitas Sumatera Utara.

Lykholat, O. A., Grigoryuk, I. P., dan Lykholat, T. Y. 2016. Metabolic effects of alimentary estrogen in different age animals. Annals of Agrarian Science. Volume 14 Nomor 4. hal : 335-339. https://doi. org/10.1016/j.aasci.2016.09.012

Yusriana, C. S., Setya Budi, C., dan Dewi, T. 2014. Uji Daya Hambat Infusa Daun Nangka (Artocarpus heterophyllus) terhadap Pertumbuhan Bakteri Staphylococcus aureus. Jurnal Permata Indonesia. Volume 5, Nomor 2, Hal : 1-7.

Sulistyorini, R., Johan, A., dan Djamiatun, K. 2013. Pengaruh Ekstrak Etanol Daun Kelor (Moringa oleifera) pada Ekspresi Insulin dan Insulitis Tikus Diabetes Melitus Effect of Ethanol Extract of Moringa oleifera Leaves on Insulin Expression and Insulitis in Diabetes Mellitus Rats. Majalah Kedokteran Bandung. Volume 47 Nomor 22. hal : 69-76.

Wahyono, T., W. T. Sasongko, M.Sholihah, dan M. R. Pikoli. 2017. Pengaruh Penambahan Tanin Daun Nangka (Artocarpus heterophyllus) terhadap Nilai Biologis Daun Kelor (Moringa oleifera) dan Jerami Kacang Hijau (Vigna radiata) Secara In Vitro. Buletin Peternakan. Volume 41 Nomor 1, Hal : 15-25. https://doi.org/10.21059/ buletinpeternak.v41i1.22450 